\title{
Review \\ Sustainable Approach to Weed Management: The Role of Precision Weed Management
}

\author{
António Monteiro ${ }^{1,2, *(D)}$ and Sérgio Santos ${ }^{1}$
}

1 Agrarian Superior School, Polytechnic Institute of Viseu, Quinta da Alagoa, 3500-606 Viseu, Portugal; sergioalvesstos@gmail.com

2 CERNAS, Research Centre for Natural Resources, Environment and Society, Polytechnic Institute of Viseu, Polytechnic Campus, 3500-606 Viseu, Portugal

* Correspondence: amonteiro@esav.ipv.pt

Citation: Monteiro, A.; Santos, S. Sustainable Approach to Weed

Management: The Role of Precision Weed Management. Agronomy 2022, 12, 118. https://doi.org/10.3390/ agronomy12010118

Academic Editor: David Clements

Received: 16 November 2021

Accepted: 31 December 2021

Published: 4 January 2022

Publisher's Note: MDPI stays neutral with regard to jurisdictional claims in published maps and institutional affiliations.

Copyright: (C) 2022 by the authors. Licensee MDPI, Basel, Switzerland. This article is an open access article distributed under the terms and conditions of the Creative Commons Attribution (CC BY) license (https:// creativecommons.org/licenses/by/ $4.0 /)$.
Abstract: In the last few decades, the increase in the world's population has created a need to produce more food, generating, consequently, greater pressure on agricultural production. In addition, problems related to climate change, water scarcity or decreasing amounts of arable land have serious implications for farming sustainability. Weeds can affect food production in agricultural systems, decreasing the product quality and productivity due to the competition for natural resources. On the other hand, weeds can also be considered to be valuable indicators of biodiversity because of their role in providing ecosystem services. In this sense, there is a need to carry out an effective and sustainable weed management process, integrating the various control methods (i.e., cultural, mechanical and chemical) in a harmonious way, without harming the entire agrarian ecosystem. Thus, intensive mechanization and herbicide use should be avoided. Herbicide resistance in some weed biotypes is a major concern today and must be tackled. On the other hand, the recent development of weed control technologies can promote higher levels of food production, lower the amount of inputs needed and reduce environmental damage, invariably bringing us closer to more sustainable agricultural systems. In this paper, we review the most common conventional and non-conventional weed control strategies from a sustainability perspective, highlighting the application of the precision and automated weed control technologies associated with precision weed management (PWM).

Keywords: agricultural production; sustainability; weed management; herbicide resistance; weed control technologies

\section{Introduction}

The world population has rapidly exceeded seven billion and is expected to reach nine billion by 2050 [1]. Current crop production levels are not adequate to feed the growing population, and meeting this anticipated demand could be a huge challenge for humanity [2]. Climate change, the scarcity of arable land and water resources and the threat from diseases, pests and weeds are additional issues [3] that make the pressure on agricultural systems greater than ever before [4], with implications, in the short and long term, for sustainability, for the planet and for the quality of life of living beings. Weeds have been a persistent problem in agriculture since its beginning [5]. Weeds hinder the growth of crops by competing with the plants for water, nutrients and sunlight, which results in large losses in crop production. Most weeds are either controlled mechanically through specific cultivation practices or with the application of herbicides [6]. However, intensive mechanization increases soil erosion [7], leading to a loss of fertility. The use of herbicides contaminates the soil, water, food and air, causing diseases in humans and animals [8], creating the phenomena of herbicide resistance and unbalancing ecosystems. From this perspective, biodiversity plays a preponderant role in the provision of ecosystem services in agricultural systems. Agrobiodiversity can have a direct effect on services when 
increased crop diversity increases food resources, or when cover crop diversity increases plant biomass, improving water quality and lowering runoff [9]. However, agrobiodiversity and services, such as pollination, improved soil structures and natural pest control, are increasingly threatened by the massive elimination of weeds and wild plants, as well as due to species' toxification by agrochemical inputs [10]. Weeds perform a range of ecosystem functions in terms of soil quality and biodiversity support, which can help to sustain agroecosystem productivity in the long term [11]. Thus, as sustainable agriculture has the capacity to save natural resources for the future and develop farms with less cost, a transition to sustainable weed control is necessary for a variety of environmental, social and economic reasons [12]. Sustainable weed management comprises a suite of weed management options, including integrated weed management (IWM) [13], which is based on the employment of a multiplicity of weed control strategies [1]. IWM aims to optimize crop production and increase grower profit through the concerted use of preventive strategies, scientific knowledge, management skills, monitoring procedures and the efficient use of control practices [14]. In this context, a wide and rapidly expanding range of new technologies have been developed and implemented in agricultural practices, which also play a key role in progress towards economically and environmentally sustainable weed management [6]. Precision weed management leads to a reduction of inputs without decreasing weed control effectiveness [1]. Studies and experiments have shown significant potential savings and technical progress in sensing, weeding and spraying technologies. Some of these technologies have been commercially exploited [6]. Thus, the current paper aims to describe conventional and non-conventional weed control strategies from a sustainability perspective, showing the value of the application of different innovations associated with PWM. The remainder of this paper is organized as follows: in Section 2, we present the search strategy chosen to carry out the literature review. In Section 3 we discuss the weed concept in the context of population ecology and the sustainability of agricultural systems. Section 4 introduces weed management techniques and discusses the conventional and non-conventional methods and their limitations. Section 5 addresses the topic of precision weed control and the current technological trends it encompasses. Finally, in Section 6 we present our conclusions regarding the potential role of precision weed control in taking integrated weed management to another level.

\section{Search Strategy}

The main motivation for carrying out this review lies in the fact that precision weed management plays a key role in farming production and sustainability. A literature analysis for the review involved a keyword-based search mainly for conference and/or journal articles. The ScienceDirect and IEEE Xplore scientific research databases, as well as the Google Scholar web scientific search engine, were selected to perform this review. We collected the information about the currently available weed management techniques, summarizing several methods for this agricultural practice. To achieve the objective proposed for this research, 119 studies were collected using the search terms "weed management" and "precision weed" without any restrictions for the years considered or language. Other keywords were also used, such as "sustainable weed management", "non-chemical weed management" or "weed technology". After excluding the duplicated studies (39 total), 80 articles were analyzed.

\section{Weeds: Threat or Benefit?}

Weeds are certainly as old as agriculture, and from the beginning, farmers recognized that the presence of those unsown plant species interfered with the growth of the crop they intended to produce [15]. The term "weed" can be defined, from an agronomical point of view, as any plant not intentionally sown or propagated by the farmer that requires management to avoid any interference with crop or livestock production [16]. Indeed, "volunteer crops", such as buckwheat, rye, Japanese millet, corn or soybean, can become 
weeds when they self-seed and emerge in another part of the crop rotation when they are no longer wanted [17].

Weeds are one of the main factors restricting food production in farming systems all over the world. By growing simultaneously with crops, weeds decrease productivity and even the quality of the harvested product, whether due to competition for water, sunlight, nutrients and space, allelopathy [18] or parasitism [17,19]. Furthermore, weeds are the costliest category of agricultural threats, causing more than $45 \%$ of loss in yields of field crops, when compared to crop diseases (25\%) or insect pests (20\%) [12]. Yield losses caused by weeds depend on several factors, such as weed emergence time, weed density, type of weeds and crops, etc. Uncontrolled weeds can result in 100\% yield loss [20]. In addition, weeds interact with other biological agents of the ecosystem, acting as a host for insects and pathogens (fungi and bacteria), which can cause serious damage to crop plants [13]. Moreover, weeds decrease land value (especially perennial and parasitic weeds), and interfere with water management (e.g., increased losses through evapotranspiration, reduced water flow in irrigation ditches, etc.) [17]. Serious weed problems develop when a susceptible crop, a large weed seed bank in the soil (including both true seeds and vegetative propagules of perennial weeds), and a favorable environment for weed growth occur together [16]. All weeds' interactions with human goals represent a permanent constraint to human activities and this justifies the employment of control tactics aimed at killing or managing as many weeds as possible. However, the complete eradication of actual (emerged plants) and potential (seed bank) weeds is unachievable [15]. The presence of weeds in the crop field also provides a series of agronomic and ecological benefits when they occur, especially at low densities [17].

Based on the ecological approach, weeds are considered to be important indicators of biodiversity, playing a key role in providing food or shelter for animal species. For example, a large proportion of the decline in farmland birds has been associated with a reduction in weed occurrence in arable crops [15]. Weeds with a deep and extensive root system can decrease soil erosion and mineral nutrient leaching, conserve soil moisture and improve soil structure [17]. Weeds can also be an indirect resource for predatory species, as, in fact, they could provide alternative food sources for the biotic agents that play a key role in pest control. A solid knowledge of the long-term dynamics of the weed population and how it is affected by different weed management strategies is critical for developing an optimum crop management strategy [15]. Agricultural practices that enhance diversity and ecosystem functioning offer, in general, potential improvements for sustaining agricultural productivity and farm livelihoods, as well as broader biodiversity and better ecosystem functioning. More diverse agroecosystems usually provide: (a) greater resilience; (b) less dependence on pesticides; (c) more reliable incomes and (d) better quality of life for the rural population [11].

\section{Weed Management and the Need for a New Paradigm}

Managing weeds has always been placed at the center of agricultural activity by farmers since ancient times [17]. The control of weeds is a big challenge in agriculture and in many cases a complex, controversial and also expensive problem to solve [10]. In fact, weed management accounts for nearly one third of the total cost of the production of field crops [12]. This agronomic practice goes beyond the control of existing weed problems and places greater emphasis on preventing weed reproduction, reducing weed emergence after crop planting and minimizing weed competition with the crop [21].

Currently, weed management in agricultural systems branches out into two distinct directions corresponding to different approaches. On the one hand is the widespread use of synthetic herbicides, while on the other, weed control is widely based on mechanical, cultural and physical methods [17]. Mechanical methods are generally inefficient, while herbicides have a negative impact on the ecosystem. In this regard, mechanical and chemical weed control has disadvantages that will probably impede their effectiveness for future weed management. Thus, weed management requires an integrated approach that 
minimizes the drawbacks of mechanical and chemical weed control [22]. Indeed, there is a great need for a new weed management paradigm in modern agriculture that is based on ecological principles and non-conventional weed management approaches [23]. Sustainable weed control for the crop can significantly influence the operation of machinery, the reduction of pest habitats (e.g., for voles) and make contributions to satisfactory economic benefits through the quality of harvested products [24], as required by the market [25].

IWM plays a key role in the weed management of the advanced cropping systems of developed countries, especially in the European Union, while it is still poorly adopted in developing countries [17]. A combined use of different weed control methods (agronomic, physical, mechanical and chemical) within a system, rather than relying on a single method [20], is required in IWM [26]. This strategy is important for reducing the selection pressure for the development of resistance to any single method of weed control [20]. Furthermore, the use of non-chemical weed tactics in minor crops is important due to the scarce availability of chemical compounds [26]. Unlike traditional processes, IWM integrates many agro-ecological practices, such as the role of conservation tillage and crop rotation on weed seed bank dynamics, the ability to predict the critical period of weed interference and its competition with crops, and the specific critical levels of crop/weed interaction [22]. In a broader context of IWM, emerging technologies have the potential to change the current approach to weed control and help significantly reduce environmental impacts, such as herbicide resistance or drift and the high cost of inputs and labor, without decreasing weed control efficacy. Several methods are being developed to observe and detect weeds so that control measures can be applied wherever and whenever they are needed. This paradigm shift is based on an interdisciplinary work to harness powerful technology tools and use them to control weeds [1]. From this perspective, we will present in the next section the PWM's contributions to weed control, which could be considered to be an important upgrade in IWM.

\subsection{Conventional Weed Control Strategies \\ 4.1.1. Herbicide Control}

The use of herbicides, also known as chemical substance applications, is at the top of weed control methods. Herbicides can improve production efficiency, facilitate reduced tillage production systems [21] and require less costs and human effort [17]. Herbicides were introduced in agriculture mainly to combat the weeds that compete with crops for nutrients and sunlight. Other common uses in the farm are to eradicate invasive plant species or undesirable plants for livestock farms [10]. A large number of herbicides have been produced and are currently under development for field crops. Herbicides can be classified according to the chemical family, the time of application (preplant, pre-emergence and postemergence), the mechanism of action, their formulation, the site of uptake and their selectivity [17]. In a similar manner to other pesticides, herbicides' active ingredients are biologically active compounds. They are designed to pass through membranes and diffuse into the interior of living cells to exert the desirable toxic action [10]. The use of herbicides should be as minimal and as efficient as possible in order to eliminate the negative environmental impacts, which can bring them a step closer to agricultural sustainability [27]. In this sense, global changes and herbicide policies in Europe compel farmers to reduce their herbicide use (Directive 2009/128/CE, 2009) in order to limit their impact on human health and the environment. In response, farmers need to replace herbicides with a combination of multiple, mostly preventive and partially efficient practices [28].

\subsubsection{Mechanical Control}

Controlling weeds via mechanical means is challenging and requires the combination of different weeding techniques and cultivation strategies to achieve economically acceptable weed control levels [29]. Mechanical weed control destroys weeds or reduces their competitive ability via physical means [30]. In addition, mechanical weeding can provide effective weed management even when other methods are not possible and can outperform 
them in some situations [31]. The choice of mechanical weeding method depends in part on practical considerations, such as the crop, soil type, price, operating costs and labor requirements [10].

Mechanical weed control is strongly associated with cultivating tillage [27,32]. Various forms of tillage are used for mechanical weed control; however, cultivating tillage is the key component in mechanical control in growing crops [30]. Cultivating tillage is carried out after crop sowing/planting to control weeds, and consists of shallow tillage with a variety of control tools, such as the tine harrow, rotary hoe or row cultivator. It includes whole-field cultivation, inter-row cultivation and intra-row cultivation [32], which are used to cultivate with the same intensity both on and between the crop rows, are used only between rows in row crops and are used to remove weeds from the row [21], respectively. Tillage has some beneficial factors, such as the capability of decomposing soil organic matter through soil disturbance, soil aeration, improved soil moisture status and the improved accessibility of organic residues to decomposers, all while being less labor intense [24]. Reduced tillage can also lead to indirect environmental benefits, including reductions in water pollution through pesticides and fertilizer runoff [33].

Mowing and cutting also have a large impact on weed control [32]. These operations are commonly used in turf, in rights of way, in vineyards, in orchards, in pastures and in forage crops [21]. These techniques are seldom efficient enough to obtain total weed control. Cutting and mowing weeds reduces their leaf area, slows their growth and decreases or prevents seed production [34]. However, weed control by cutting or mowing may be complicated due to the adaptation mechanisms to continuous defoliation of some weeds, especially perennial ones in grasslands. A high frequency of cutting of these weeds is required to achieve high degrees of weed control [32].

\subsection{Non-Conventional Weed Control Strategies}

\subsubsection{Mulching}

Covering the soil with plant residues/wastes or synthetic materials, commonly referred as "mulching", is one of the most popular management methods which can decrease weed issues, either by preventing weed seed germination altogether, or by blocking the growth of emerging seedlings [10]. It also promotes the sustainable management of water and biodiversity [19]. The additional advantage of mulching includes the management of temperature fluctuations and improved physical, chemical and biological characteristics of the soil. Mulches are available in distinct ways, including natural mulches, such as straw, sawdust, weeds, paper and plant residues, and synthetic mulches, such as plastic [25]. Materials, such as black polyethylene, have been used for weed control in a range of agricultural production systems [12], namely in horticultural crops (e.g., strawberry, tomato, eggplant, muskmelon, watermelon, etc.) [26]. Plastic mulches have been developed that filter out photosynthetically active radiation but let through infrared light to warm the soil. These infrared-transmitting mulches have been shown to be effective at controlling weeds [12]. Mulching is usually more effective against annual weeds rather than perennial weeds (e.g., Cyperus spp., Elymus repens (L.) Gould., Cynodon dactylon (L.), Sorghum halepense (L.) Pers.) because they greatly perforate plastic [16].

\subsubsection{Cover Crops and Living Mulches}

The adoption of a cover crops strategy can improve farm sustainability. A cover crop is any living ground cover that is planted into or after a main crop and then commonly eliminated before the next crop plantation [35]. Cover crops suppress weeds by occupying their ecological niche and competing for resources, while their soil surface residues inhibit weeds through physical, biotic and allelopathic interactions. The cover crop species can inhibit weed seed germination through the deposition of allelochemical compounds, which may be secreted both from living plants and decaying cover crop residues. Those species can be grown in rotation at times when crops are not being grown or simultaneously during part or all of the commercial growing season [34]. Cover crops enhance soil quality and 
carbon sequestration, facilitate machinery passage and increase microbial, vegetal and animal biodiversity [36]. However, the great benefits of cover crops as weed mitigators are usually associated with high cover crop biomass or rapid soil cover. If biomass and residues are scarce or decompose within a short period of time, herbicide use might be needed, depending on weed pressure. In this sense, choosing the best-adapted vegetation cover species is critical [37]. In addition, the choice of proper termination methods for cover crops can influence weed suppression capacity. Rolling-crimping and flail-mowing are effective mechanical methods for cover crop termination. Flail-mowing results in small fragments of material that decompose faster and are less persistent as mulch. Rolling flattens the cover down to form a mulch layer that decomposes slowly, when compared with flailing, and can provide more complete ground cover [38].

Living mulches are cover crops sown previously or at the same time as the main crop and maintained as a living ground cover throughout the growing season. If the living mulch is a perennial, it may be possible to maintain it without the need for reseeding every year [35]. Living mulches can decrease nutrient leaching, especially of nitrates, along with the absorption of carbon and nitrogen $[39,40]$, and provide efficient control of soil erosion, build up the organic matter for better soil structure, and provide a habitat for beneficial insects [25]. Some conditions are essential to improve the efficiency of the living mulches, such as areas with fertile soils, a sufficient water supply and the absence of perennial weed species. In addition, living mulches should be used only with established crops, as the competition for water and nutrients is much greater in the early stages of plant growth [24].

\subsubsection{Soil Solarization}

Soil solarization is an eco-friendly and cost-saving process of soil disinfestation [41], compatible with organic and integrated crop management systems [42], that uses the sun's heat to control weeds [43]. This method consists of placing a cover, such as a black or transparent plastic, over the soil surface to trap solar radiation and promote an increase in soil temperature [34]. The plastic cover must stay on the soil surface for 4 to 12 weeks [22]. In order to be effective for weed control, the soil needs to be kept moist during that time and, for large areas, preferably under drip irrigation [40], and intense radiation throughout the day is required [34]. This process is particularly applicable for the Mediterranean climate and similar climates due to the occurrence of high air temperatures in the summer [44], and higher exposure to high-energy electromagnetic radiation. Soil solarization allows farmers to maintain a high soil temperature $\left(>40 \mathrm{~b}{ }^{\circ} \mathrm{C}\right)$, which is enough to eliminate weed seeds, plants, insects and plant pathogens, such as nematodes and fungal diseases. The application of solarization is generally restricted to vegetable and minor crops (e.g., tomato, radish, lettuce, colewort, cucumber and pepper) under greenhouse cultivation, although it is considered to be effective also in open field conditions [26].

\subsubsection{Thermal Weed Control}

The thermal control of weeds is based on the use of fire, flaming, hot water, steam and freezing, which provide rapid weed control without leaving chemical residues in the soil and water. Moreover, thermal methods are selective towards the weeds, do not disturb the soil and, therefore, do not bring the buried seeds to the soil surface, as is the case with cultivation methods [34]. Flaming is the thermal method most commonly applied in organic and conventional farming systems, and relies on propane gas burners or, recently, renewable alternatives, such as hydrogen, to generate combustion temperatures up to $1900{ }^{\circ} \mathrm{C}$ [17], rapidly raising the temperature of the exposed plant tissues. Heat injury causes the destruction of plant membranes, which results in the loss of cell function. Eventually, the plants die or become severely weakened [43]. Dicotyledonous and young weed plants are more sensitive compared to developed plants and grass species [26]. Flaming is most effective at controlling erect and broad-leaved weeds in an early stage of growth, and it has been shown to be less effective in the control of grassy and prostrate weeds [25]. It should be noted that flaming should not be confused with burning, since plant 
tissues do not ignite, but heat rapidly up to the point of rupturing the cell membranes [17]. As an alternative to herbicides, the efficiency of flaming can be enhanced by its integration with tillage or mulching strategies [25]. Although thermal weed methods do not leave chemical residues in the soil and water, this approach uses large amounts of fossil fuels per unit area. The effectiveness of thermal means on weeds can be influenced by several factors, including temperature, exposure time and energy input [34].

\subsubsection{Weed Control through Livestock Grazing}

There is a readily available and under-exploited method that is fast proving very effective for weed control: livestock grazing. Incorporating grazing management into weed management plans has been recognized as one of the key components in successfully addressing weed problems [45]. Furthermore, in the agroforestry systems, for example, the combination of livestock with trees and shrubs provides multiple benefits, including biodiversity conservation and improved soil fertility [46]. Weed control with livestock grazing aims to manipulate patterns of defoliation to place a target plant at a competitive disadvantage relative to other plants in the community [45]. The efficacy and conservation benefits of targeted grazing can vary based on the timing, duration and intensity of grazing, as well as the grazing species [29]. In most cases, grazing does not eradicate a mature infestation of weeds. For successful weed control, grazing animals must be fenced into or off an area in order to adjust the grazing pressure. The ability to concentrate stock on weed infestations at some stages of growth or times of the year, and the ability to keep them off pasture or weeds at other times, is often the key to weed control [47]. Cattle, sheep and goats are ruminants and the most common animals used for weed control. Combining ruminant grazing with other weed management tools can offer an integrated approach that may be very cost effective $[19,47]$. In particular, sheep are a great tool for managing weed problems [43]. Increasingly, farmers are coming to view grazing sheep as an effective way to manage weeds and cover crops instead of chemicals, tillage or mowing. For example, sheep can replace the use of herbicides or mowing to manage floor vegetation in vineyards and orchards. Important considerations when grazing with sheep include the need for regular rotations, temporary fencing and protection against predators. In addition, sheep should not be able to eat the crop itself, which is essential for vineyard managers, for example [48].

\subsection{Limitations of Conventional and Non-Conventional Weed Control Strategies}

Apart from the advantages of using herbicides for weed control, there are also disadvantages, mainly due to limitations of the conventional spraying technologies [27]. Continuous use of the same group of herbicides over a period of time on the same piece of land leads to ecological imbalance in terms of weed shift, herbicide resistance in weeds and environmental pollution [12]. Indeed, the overuse of herbicides with the same mode of action may lead to the development of herbicide-resistant weed populations [32]. As a result, agricultural landscapes now tend to be dominated by a few weed species that are difficult to control and that provide a poor resource for farmland biodiversity [11]. For example, cutleaf evening primrose (Oenothera laciniata Hill) has become resistant to glyphosate and paraquat [22]. Herbicides can also have negative side effects, such as surface and ground water contamination, as well as leaving herbicide residues in the food chain [32,49]. In addition, chemical herbicides can substantially decrease the soil microbial communities and earthworm populations, and the persistent effects of weed suppression can lead to the reduction of nutrient availability and soil biodiversity [25].

In the same way, the excessive use of tillage results in substantial harmful effects on the soil quality parameters, including biological diversity, soil structure and water storage capacity. Tillage reduces the supply of carbon and nitrogen nutrients to microorganisms [25]. Soil erosion and soil degradation, inherent in tillage-based systems, increase the environmental pollution from agricultural chemical inputs, such as fertilizers and pesticides, compromising the sustainability of crop production and ecosystem services, as 
well as threatening global food security in the long run [15]. Moreover, the operation may face limitations owing to adverse weather conditions. There are also potential problems associated with minimum tillage or non-tillage. The bulk density and compaction of the topsoil increases, and the phytosanitary situation worsens with a higher spread of fungal diseases and the weed infestation of crops [50]. Furthermore, farmers using reduced tillage may choose to rely increasingly on herbicides and pesticides to deal with these threats [38] and, as a result, the phytotoxicity of the soil increases.

Ground cover methods, flaming or livestock grazing for weed control also have a few limitations. For example, mulching is cost intensive on a large scale, can promote changes in the soil due to the continuous use of the same mulching material and some of the organic mulches have allelopathic effects on crops [51]. In addition, many types of organic mulching, such as grass and straw, contain seeds which could allow weeds to grow and acidify the soil [52]. Cover crops incur expenses for novel equipment, more complicated management practices and time spent seeding and eliminating cover crops instead of managing cash crops [53]. Living mulches can reduce main crop growth and yield due to competition for water and nutrients, increase pest populations and the risk of diseases. Moreover, living mulches can also promote allelopathy [54]. Soil solarization induces high temperatures that can be lethal to bacteria and fungi. In some species, if the lethal temperature is not reached, dormancy can be broken, allowing an emergence of a new flush of weed seedlings. This can occur along the topsoil layer [22]. Solarization tends to result in a flush of nutrients which should be managed by immediately establishing the crop after plastic removal to prevent nutrient loss [40]. In a flaming strategy, fuel and water consumption can be high, and the flame has restrictions for use during the summer from a fire prevention standpoint. However, smaller, more portable units are now available and provide another tool for the spot control of escape weeds or around sheds and other pieces of infrastructure [26]. Finally, weed control via livestock grazing can cause damage to the soil structure and non-target species, lead to the spread of weed seeds in feces or on wool, hair or hooves, or even cause the loss of animal condition or liveweight [55].

Some of the limitations described above can be mitigated or even eliminated when technology associated with PWM is integrated. The use of the internet, the various types of sensors, artificial intelligence or machine learning can provide potential improvements to IWM. It may be said that we are entering a new era of agriculture, Agriculture 4.0, where precision is the rule [56].

\section{Precision Weed Management}

Smart farming technologies, such as smart sensors, remote sensing, air vehicles, satellites, the Internet of Things (IoT) technology, etc., are becoming increasingly common in modern agriculture to assist in optimizing agricultural production and minimizing the wastes and costs [57]. Precision farming or site-specific crop management is a concept based on sensing or observing and responding with management actions to spatial and temporal variability in crops. The "sensing" component of the concept is a fundamental element of precision farming [58], as is variable rate technology (VRT), which offers an effective way to protect the environment and increase economic benefits [59]. This technology works by integrating a variable rate control system with a sprayer for fertilizer, pesticide or herbicide applications. The application at a varied rate can be fundamentally based on maps or sensors [60]. Indeed, there are two main methods for implementing site-specific variable rate applications (VRA): map-based VRA, which adjusts the application rate of a crop production input based on the information contained in a digital map of field properties, and sensor-based systems that use data from real-time sensors to match inputs to the needs of the soil and crop [61]. From this perspective, precision farming technologies can provide many benefits for weed management practices [21]. As mentioned above, weeds are a persistent problem, and the continuing rise in numbers of herbicide-resistant biotypes reinforces the lesson that weed control technology (Table 1) must constantly advance to stay ahead of weed evolution and adaptation [2]. 
Table 1. Overview of precision weed control technologies.

\begin{tabular}{|c|c|c|c|c|}
\hline $\begin{array}{l}\text { Weed Control } \\
\text { Technologies }\end{array}$ & Method & Remarks & Drawbacks & Ref. \\
\hline UAV's & $\begin{array}{l}\text { Combination of UAVs and } \\
\text { GPS technologies }\end{array}$ & $\begin{array}{l}\text { Fast and precise in situ } \\
\text { remote sensing or survey } \\
\text { operations. Excellent } \\
\text { control in the presence of } \\
\text { obstacles, no compaction } \\
\text { and minimal } \\
\text { labor involved. }\end{array}$ & $\begin{array}{l}\text { These systems do not offer } \\
\text { the same territorial } \\
\text { coverage as satellites. } \\
\text { Some technology literacy } \\
\text { is required. }\end{array}$ & [13] \\
\hline $\begin{array}{l}\text { Hyperspectral } \\
\text { imaging sensors }\end{array}$ & $\begin{array}{l}\text { Hyperspectral imaging } \\
\text { system coupled to a } \\
\text { micro-spray heated oil } \\
\text { application system }\end{array}$ & $\begin{array}{l}\text { Less computationally } \\
\text { intensive. } \\
\text { Robust to visual occlusion } \\
\text { of the leaf margin. } \\
\text { Customizable spray } \\
\text { application for various } \\
\text { herbicides based on } \\
\text { weed species. }\end{array}$ & $\begin{array}{l}\text { Requires a multi-season } \\
\text { calibration process. }\end{array}$ & {$[62]$} \\
\hline Automatic weeders & $\begin{array}{c}\text { Intra-row robotic } \\
\text { weeder (Robovator) }\end{array}$ & $\begin{array}{l}\text { Recognition of the crop } \\
\text { row and the size difference } \\
\text { between the crop and weed. } \\
\text { Removes } 95 \% \text { of weeds. }\end{array}$ & $\begin{array}{l}\text { The machine cannot } \\
\text { distinguish between weed } \\
\text { and crop. It can only } \\
\text { distinguish between small } \\
\text { and large plants. }\end{array}$ & {$[25,63]$} \\
\hline $\begin{array}{l}\text { Precision spray } \\
\text { systems }\end{array}$ & $\begin{array}{l}\text { Autonomous robot for } \\
\text { precision spraying }\end{array}$ & $\begin{array}{l}\text { Autonomously sprays } \\
\text { targets with high accuracy. }\end{array}$ & N.A. & [63] \\
\hline Weed sprayers & $\begin{array}{l}\text { Machine vision weed } \\
\text { spot-sprayer }\end{array}$ & $\begin{array}{l}\text { Distinguishes weed leaves } \\
\text { from maize plants with } \\
\text { more than } 90 \% \text { accuracy. }\end{array}$ & N.A. & {$[64]$} \\
\hline
\end{tabular}

A wide range of weed sensing techniques have been studied since the beginning of the century. With large areas, the most cost-effective approach may be remote sensing to provide a farm, or a large area encompassing several farms, with maps of weed occurrence [6]. Remote sensing uses satellite or manned/unmanned aerial vehicles to collect data. Satellite-based remote sensing is well suited for surveying a large area and can help with large-scale crop yield monitoring. Satellite imagery lacks precision in assessing small areas, especially for weed detection, spatial distribution and herbicide injury evaluations. These tasks require high-resolution imagery, which is typically achieved through closer observations using manned/unmanned aerial or ground vehicles [65].

Unmanned aerial vehicles (UAVs) can be highly valuable, since they allow for sitespecific weed management (SSWM), an improved weed management approach for the highly efficient and environmentally safe control of weed populations, enabling precise and continuous monitoring and mapping of weed infestation [13]. In addition, there are other advantages to using UAV technology. Indeed, UAVs provide helpful information for the precise application of amounts of water in the required field, contributing to water savings in agriculture [66]. Additionally, the use of UAVs for spraying and seeding purposes can prevent problems of subsoil compaction [67]. This technology also has the potential to minimize soil degradation, the loss of soil fertility and the subsequent contamination of water due to the excessive use of fertilizers, and can potentially save time by tremendously reducing inspection times [68]. The applications of UAVs have been increasing in forestry, rangeland ecology and agronomic cropping systems, among several other fields [65]. The combination of UAVs with advanced cameras and sensors, able to discern specific weeds, and global navigation satellite system (GNSS) or global positioning system (GPS) technologies, which provide geographical information for field mapping, can help in precisely monitoring large areas in a few minutes. Currently, UAVs stand out among the other remote sensing platforms, as they can fly at low altitudes, capture images with millimetric accuracy and provide data on demand in critical moments, which are not 
feasible with aerial or satellite platforms [69]. When compared to unmanned ground vehicles (UGVs), UAVs take less time to monitor or survey the crop field and have optimal control in the presence of any natural barrier, which is critical when working between crop rows [70]. Mainly three types of cameras are used for weed identification with UAVs: red, green and blue (RGB), multispectral and hyperspectral cameras, which can recognize weed patches with good accuracy depending on the flying altitude, camera resolution and UAV used. Therefore, the combined use of UAVs and image processing technologies may help to effectively control different weed species interfering with the crops with relevant environmental benefits [13].

Multispectral and hyperspectral imaging sensors mounted on UAVs have been used successfully to detect weeds and distinguish species. This kind of technology can provide valuable information that is not obtained by RGB cameras or not visible to the naked eye. In particular, hyperspectral imaging has been used more often to classify agricultural systems and vegetation because it has more bands compared to that of multispectral sensors [65]. In fact, the most powerful and, to date, the only method capable of robust, automated in-field discrimination of individual plant species is based upon hyperspectral imaging. The hyperspectral imaging concept has been demonstrated in the field with lettuce (Lactuca sativa L.) and tomato (Lycopersicum esculentum Mill.) crops, with betweenspecies pixel-level recognition rates above $75 \%$ and crop vs. weed discrimination rates above $90 \%$ [43]. For example, Zhang et al. [62] developed a hyperspectral imaging system coupled to a micro-spray heated oil application system for weed control within the seed lines of early growth tomatoes. According to the authors, the hyperspectral imaging system correctly identified $95 \%, 94 \%$ and $99 \%$ of tomatoes, black night shade and pigweed, respectively. This technology is less computationally intensive than shape-based pattern recognition, it is robust to visual occlusion of the leaf margin and the species recognition ability can be used to customize the spray application of multiple herbicidal materials based upon the weed species. However, the requirement of a multi-season calibration process is a disadvantage of this method [37].

Automation technologies and mechatronics are likely to become more effective and commercially viable as future weed control strategies and they are already being used in industrialized countries with specific crops [71]. Typically, vegetable crops, such as broccoli, cabbage, field-grown flowers, herbs, lettuce, onion and tomato, among others, are hand weeded to achieve intra-row weed control. In this sense, the industry has responded to the need for automation of intra-row cultivators [2] as a viable alternative to hand weeding [47]. According to Peruzzi et al. [72], four kinds of intra-row robotic weeders are commercially available for precision weed-management systems: Robovator (Frank Poulsen Engineering Aps., Hvalsø, Denmark); Robocrop (Tillett and Hague Technology Ltd., Greenfield, Bedfordshire, England); IC-cultivator (Machinefabriek Steketee BV, Haringvliet, The Netherlands); and Remoweed (Costruzioni Meccaniche Ferrari, Guidizzolo MN, Italy). Robovator is considered to be the most effective intra-row weedmanagement system, and is used predominantly in organic farming [25]. The Robovator system is designed to detect the difference between the crop plant and weed based on the recognition of the crop row and the size difference between the crop and weed. With the Robovator, each row has a camera, and images from the cameras are processed to determine the position of the crop, and then the computer signals the actuator to operate at the proper location. The Robovator intelligent cultivator was evaluated with different types of crops [43]. With broccoli and lettuce, for example, the Robovator reduced hand-weeding time by $39 \%$ and $27 \%$, respectively, compared with the standard cultivator [2]. Interest in automation of weed sprayers has been rising in recent decades [73]. Precision spraying is able to minimize the amount of herbicide needed on a given crop, compared with traditional broadcast sprayers that usually treat the entire field to control weed populations, which potentially results in unnecessary application to areas that do not require treatment. The application of herbicide in a specific location, i.e., where weeds occur, could reduce costs, the risk of crop damage and excess pesticide residue, as well as potentially reducing 
the environmental impact [27]. The effectiveness of precision spray systems is based on high levels of crop/weed differentiation, accurate spray prescription maps, the knowledge of the sprayer tip location relative to the target weed location, accurate herbicide placement and control of the spray drift [43]. For example, spot spraying systems provide potential savings with herbicide use, which can range from $5 \%$ to nearly $90 \%[6,74,75]$, depending mainly on the spatial and temporal distribution of weeds found in the treated fields. In addition, according to Jensen et al. [76], the detailed and resource-efficient approach of herbicide spraying with SSWM in smart farming can decrease herbicide consumption by $40 \%$ to $60 \%$. An autonomous robot for precision spraying was developed by Søgaard and Lund [63]. According to the authors, the system was able to deliver lower doses $(2.5 \mu \mathrm{L})$ autonomously by spraying targets with sub-centimeter accuracy. The system was further tested in field trials planted with oilseed rape as a test weed. In the study, the plant surface area was found to have a large effect on machine performance [27]. Additionally, Kargar and Shirzadifar [64] developed a machine vision weed spot sprayer for maize fields. The system used image segmentation and feature extraction to distinguish the grass leaves from maize plants with over $90 \%$ accuracy. As corn leaves are much wider than grass, the detection accuracy is increased. Lastly, H-Sensor (Agricon GmbH, Ostrau, Germany) and See and Spray (Blue River Technology, Sunnyvale, CA, USA) are commercial spraying systems that use artificial intelligence and are able to distinguish between crop plants and several weeds [27].

\section{Conclusions}

With the growth of the world population and the consequent need to ensure the supply of food by increasing agricultural production, there is a need for improved management of the world's agricultural resources while minimizing the negative impact on the environment. From an agronomic point of view, weeds are considered to be a threat with serious implications for agricultural efficiency, causing yield losses. However, from an ecological perspective, they can also be considered to be valuable indicators of biodiversity in the agrarian ecosystem, as well as providers of ecological services as a component of the agroecosystem. Weed management involves several methods. Nevertheless, a single method of control will not provide adequate long-term weed management, and instead often results in increasing resistance. Therefore, the need to integrate different weed control methods under a holistic approach is critical.

The use of herbicides creates imbalances in the ecosystem, even causing the resistance of some species to the continued use of these chemical agents. In addition, no less serious are the environmental problems they cause and their consequent threat to the well-being and health of animals and humans.

Thus, the sustainable management of the agricultural system, namely of weeds, is an important issue for the present and future of humanity. In addition to integrated management, the development of precision technologies inherent to weed control can be a valuable contribution to improved sustainability and agricultural yield. In this sense, we would suggest a more effective involvement of researchers and farmers with the integration of ecological and technological principles into weed management decision making.

Author Contributions: Conceptualization, A.M.; methodology, A.M. and S.S.; software, S.S. and A.M.; validation, A.M; formal analysis, A.M.; investigation, A.M. and S.S.; resources, A.M. and S.S.; data curation, S.S.; writing-original draft preparation, A.M. and S.S.; writing-review and editing, A.M.; visualization, S.S. and A.M.; supervision, A.M.; project administration, A.M.; funding acquisition, A.M. All authors have read and agreed to the published version of the manuscript.

Funding: This research was funded by the FCT-Foundation for Science and Technology, I.P., Portugal, within the scope of the project Ref. UIDB/00681/2020. The APC was funded by FCT-Ref. UIDB/00681/2020.

Institutional Review Board Statement: Not applicable.

Informed Consent Statement: Not applicable. 


\section{Data Availability Statement: Not applicable.}

Acknowledgments: The authors would like to acknowledge support from the FCT-Foundation for Science and Technology, I.P., within the scope of the project Ref. UIDB/00681/2020, as well as the CERNAS Research Centre and the Polytechnic Institutes of Viseu for their support.

Conflicts of Interest: The authors declare no conflict of interest.

\section{References}

1. Young, S.; Pierce, J. Automation: The Future of Weed Control in Cropping Systems; Springer: Berlin/Heidelberg, Germany, 2014; pp. 249-259. [CrossRef]

2. Westwood, J.; Charudattan, R.; Duke, S.; Fennimore, S.; Marrone, P.; Slaughter, D.; Swanton, C.; Zollinger, R. Weed Management in 2050: Perspectives on the Future of Weed Science. Weed Sci. 2018, 66, 275-285. [CrossRef]

3. Wang, A.; Zhang, W.; Wei, X. A review on weed detection using ground-based machine vision and image processing techniques. Comput. Electron. Agric. 2019, 158, 226-240. [CrossRef]

4. Seelan, S.; Laguette, S.; Casady, G.M.; Seielstad, G.A. Remote sensing applications for precision agriculture: A learning community approach. Remote Sens. Environ. 2003, 88, 157-169. [CrossRef]

5. Fontanelli, M.; Frasconi, C.; Martelloni, L.; Pirchio, M.; Foster, R. Weed management in autumn fresh market spinach: A nonchemical alternative. HortTechnology 2015, 25, 177-184. [CrossRef]

6. Christensen, S.; Søgaard, H.T.; Kudsk, P.; Nørremark, M.; Lund, I.; Nadimi, E.S.; Jørgensen, R. Site-specific weed control technologies. Weed Res. 2009, 49, 233-241. [CrossRef]

7. Guccione, G.; Schifani, G. Technological innovation, agricultural mechanization and the impact on the environment: Sod seeding and minimum tillage. Prospettive e proposte mediterranee. J. Econ. Agric. Environ. 2001, 3, 29-36.

8. Ribas, P.; Matsumura, A. A química dos agrotóxicos: Impacto sobre a saúde e meio ambiente. The chemistry of pesticides: Impact on health and the environment. Rev. Lib. 2009, 10, 149-158.

9. Wood, S.A.; Karp, D.S.; DeClerck, F.; Kremen, C.; Naeem, S.; Palm, C.A. Functional traits in agriculture: Agrobiodiversity and ecosystem services. Trends Ecol. Evol. 2015, 30, 531-539. [CrossRef]

10. PAN-Pesticide Action Network Europe. Alternative Methods in Weed Managment to Glyphosate; Intergrated Weed Management. Pesticide Action Network Europe: Brussels, Belgium, 2017. Available online: https:/ /www.pan-europe.info/sites/pan-europe. info/files/Report_Alternatives\%20to\%20Glyphosate_July_2018.pdf (accessed on 23 September 2021).

11. MacLaren, C.; Storkey, J.; Menegat, A. An ecological future for weed science to sustain crop production and the environment. A review. Agron. Sustain. Dev. 2020, 40, 24. [CrossRef]

12. Gnanavel, I. Eco-Friendly Weed Control Options for Sustainable Agriculture. Sci. Int. 2015, 3, 37-47. [CrossRef]

13. Esposito, M.; Crimaldi, M.; Cirillo, V. Drone and sensor technology for sustainable weed management: A review. Chem. Biol. Technol. Agric. 2021, 8, 18. [CrossRef]

14. Hartzler, R.; Buhler, D. Management of agricultural weeds. Ecologically Based Integrated Pest Management. In Opender KoulGerrit and W. Cuperus; CABI: Wallingford, UK, 2007; pp. 37-51. ISBN 9781845931636.

15. Radicetti, E.; Mancinelli, R. Sustainable Weed Control in the Agro-Ecosystems. Sustainability 2021, 13, 8639. [CrossRef]

16. Schonbeck, M. Principles of Sustainable Weed Management in Organic Cropping Systems, 3rd ed.; Workshop for Farmers and Agricultural Professionals on Sustainable Weed Management; Clemson University: Clemson, SC, USA, 2011.

17. Scavo, A.; Mauromicale, G. Integrated Weed Management in Herbaceous Field Crops. Agronomy 2020, 10, 466. [CrossRef]

18. Monteiro, A.; Souza, M.; Lins, H.; Teófilo, T.; Júnior, A.; Silva, S.; Mendonça, V. A new alternative to determine weed control in agricultural systems based on artificial neural networks (ANNs). Field Crop. Res. 2021, 263, 108075. [CrossRef]

19. ADVID—Associação para o Desenvolvimento da Viticultura Duriense. Diferentes Estratégias Para o Controlo de Infestantes em Viticultura de Encosta. Different Strategies for Weed Control in Hillside Viticulture. 2019. Available online: https://www. advid.pt/uploads/DOCUMENTOS/Subcategorias/Comunicacao/MANUAL_INFESTANTES_FINAL_WEB.pdf (accessed on 30 August 2021).

20. Chauhan, B.S. Grand Challenges in Weed Management. In Frontiers in Agronomy; Frontiers Media SA: Lausanne, Switzerland, 2020; Volume 1. [CrossRef]

21. Ghosheh, H. Precision Weed Management Research Advancement in the Near East Global Proliferation of Precision Agriculture and its Applications. 2010. Available online: https:/ / www.ispag.org/proceedings / ?action=abstract\&id=137\&title=Precision+ Weed+Management+Research+Advancement+In+The+Near+East+\&search=types (accessed on 7 September 2021).

22. Sims, B.; Corsi, S.; Gbehounou, G.; Kienzle, J.; Taguchi, M.; Friedrich, T. Sustainable Weed Management for Conservation Agriculture: Options for Smallholder Farmers. Agriculture 2018, 8, 118. [CrossRef]

23. Korresa, N.E.; Burgosa, N.; Trovlos, I.; Vurro, M.; Gitsopoulos, T.; Varanasi, V.; Duke, S.; Kudsk, P.; Brabham, C.; Rouse, C.; et al. Chapter Six-New directions for integrated weed management: Modern technologies, tools and knowledge discovery. Adv. Agron. 2019, 155, 243-319. [CrossRef]

24. Hammermeister, A. Organic weed management in perennial fruits. Sci. Hortic. 2016, 208, 28-42. [CrossRef]

25. Mia, M.J.; Massetani, F.; Murri, G.; Neri, D. Sustainable alternatives to chemicals for weed control in the orchard-A Review. Hortic. Sci. 2020, 47, 1-12. [CrossRef] 
26. Pannacci, E.; Lattanzi, B.; Tei, F. Non-chemical weed management strategies in minor crops: A review. Crop. Prot. 2017, 96, 44-58. [CrossRef]

27. Partel, V.; Kakarla, S.C.; Ampatzidis, Y. Development and evaluation of a low cost and smart technology for precision weed management utilizing artificial intelligence. Comput. Electron. Agric. 2019, 157, 339-350. [CrossRef]

28. Colas, F.; Cordeau, S.; Granger, S.; Jeuffroy, M.H.; Pointurier, O.; Queyrel, W.; Rodriguez, A.; Villerd, J.; Colbach, N. Codevelopment of a decision support system for integrated weed management: Contribution from future users. Eur. J. Agron. 2020, 114. [CrossRef]

29. Lehnhoff, E.A.; Rew, L.J.; Mangold, J.M.; Seipel, T.; Ragen, D. Integrated Management of Cheatgrass (Bromus tectorum) with Sheep Grazing and Herbicide. Agronomy 2019, 9, 315. [CrossRef]

30. Lingenfelter, D.; Curran, W. Weed Management in Pasture Systems. In Agronomy Facts 62; College of Agricultural Sciences, Penn State Extension: Pennsylvania, PA, USA, 2001. Available online: https:/ / extension.psu.edu/weed-management-in-pasturesystems (accessed on 3 September 2021).

31. Hinds, J. A Whole-Farm Approach to Managing Pests. SARE-Sustainable Agriculture Research and Education. 2020. Available online: https:/ / www.sare.org/wp-content/uploads/A_Whole-Farm_Approach_to_Managing_Pests.pdf (accessed on 16 January 2020).

32. Rueda-Ayala, V.; Rasmussen, J.; Gerhards, R. Mechanical Weed Control. In Precision Crop Protection-the Challenge and Use of Heterogeneity; Oerke, E.C., Gerhards, R., Menz, G., Sikora, R., Eds.; Springer: Dordrecht, The Netherlands, 2020. [CrossRef]

33. Van Acker, R.; Rahman, M.; Cici, S. Pros and Cons of GMO Crop Farming. Oxford Research Encyclopedia of Environmental Science. Available online: https:/ / oxfordre.com/environmentalscience/view/10.1093/acrefore/9780199389414.001.0001/acrefore9780199389414-e-217\#acrefore-9780199389414-e-217-bibliography-0001 (accessed on 9 November 2021).

34. Radicetti, E. Ecological Weed Management. Ph.D. Thesis, Università degli Studi della Tuscia Di Viterbo, Viterbo, Italy, 2012. [CrossRef]

35. Hartwig, N.; Ammon, H. Cover crops and living mulches. Weed Sci. 2002, 50, 688-699. [CrossRef]

36. Sportelli, M.; Frasconi, C.; Fontanelli, M.; Pirchio, M.; Raffaelli, M.; Magni, S.; Caturegli, L.; Volterrani, M.; Mainardi, M.; Peruzzi, A. Autonomous Mowing and Complete Floor Cover for Weed Control in Vineyards. Agronomy 2021, 11, 538. [CrossRef]

37. Želazny, W.; Licznar-Malanczuk, M. Soil quality and tree status in a 12-year-old apple orchard under three mulch-based floor management systems. Soil Tillage Res. 2018, 180, 250-258. [CrossRef]

38. Wayman, S.; Cogger, C.; Benedict, C.; Burke, I.; Collins, D.; Bary, A. The influence of cover crop variety, termination timing and termination method on mulch, weed cover and soil nitrate in reduced-tillage organic systems. Renew. Agric. Food Syst. 2015, 30, 450-460. [CrossRef]

39. Büchi, L.; Wendling, M.; Amossé, C.; Jeangros, B.; Charles, R. Cover crops to secure weed control strategies in a maize crop with reduced tillage. Field Crop. Res. 2020, 247, 107583. [CrossRef]

40. Merfield, C. Organic Weed Management: A Practical Guide. 2002. Available online: https://researcharchive.lincoln.ac.nz/ bitstream/handle/10182/4902/Merfield_organic_weed_2002.pdf?sequence=1\&isAllowed=y (accessed on 18 August 2021).

41. Candido, V.; Addabbo, T.; Basile, M.; Castronuovo, D.; Miccolis, V. Greenhouse soil solarization: Effect on weeds, nematodes and yield of tomato and melon. In Agronomy for Sustainable Development; Springer/EDP Sciences/INRA: Berlin/Heidelberg, Germany, 2008; Volume 28, pp. 221-230. [CrossRef]

42. Peerzada, A.M.; Chauhan, B.S. Thermal weed control: History, mechanisms, and impacts. In Non-Chemical Weed Control, 1st ed.; Peerzada, A.M., Chauhan, B.S., Eds.; Academic Press: Cambridge, MA, USA, 2018; pp. 9-31. [CrossRef]

43. Fennimore, S.; Slaughter, D.; Siemens, M.; Leon, R.; Saber, M. Technology for Automation of Weed Control in Specialty Crops. Weed Technol. 2016, 30, 823-837. [CrossRef]

44. Oka, Y.; Shapira, N.; Fine, P. Control of root-knot nematodes in organic farming systems by organic amendments and soil solarization. Crop. Prot. 2007, 26, 1556-1565. [CrossRef]

45. Frost, R.; Launchbaugh, K. Prescription Grazing for Rangeland Weed Management A new look at an old tool. Rangelands 2003, 25, 43-47. [CrossRef]

46. Wilson, M.H.; Lovell, S.T. Agroforestry-The Next Step in Sustainable and Resilient Agriculture. Sustainability 2016, 8, 574. [CrossRef]

47. Melander, B.; Liebman, M.; Davis, A.S.; Gallandt, E.R.; Bàrberi, P.; Moonen, A.; Rasmussen, J.; van der Weide, R.; Vidotto, F. Non-Chemical Weed Management. In Weed Research; Hatcher, P.E., Froud-Williams, R.J., Eds.; Wiley: New York, NY, USA, 2017. [CrossRef]

48. Gonçalves, P.; Nóbrega, L.; Monteiro, A.; Pedreiras, P.; Rodrigues, P.; Esteves, F. SheepIT, an E-Shepherd System for Weed Control in Vineyards: Experimental Results and Lessons Learned. Animals 2021, 11, 2625. [CrossRef] [PubMed]

49. Lancaster, S.R. Chemical Weed Control for Field Crops, Pastures, Rangeland, and Noncropland; Kansas State University: Manhattan, KS, USA, 2021; p. 148. Available online: https://www.bookstore.ksre.ksu.edu/pubs/CHEMWEEDGUIDE.pdf (accessed on 23 September 2021).

50. Zhelezova, S.V.; Melnikov, A.V.; Ananiev, A.A. Pros and cons of no-till technology in a long-term field experiment on sod-podzolic soil. IOP Conf. Ser. Earth Environ. Sci. 2019, 368, 012055. [CrossRef]

51. Peera, P.; Debnath, S.; Maitra, S. Mulching: Materials, Advantages and Crop Production. In Protected Cultivation and Smart Agriculture; Sagar, M., Dinkar, J.G., Tanmoy, S., Eds.; New Delhi Publishers: New Delhi, India, 2020; pp. 55-66. [CrossRef] 
52. Kader, M.A.; Singha, A.; Begum, M.A.; Jewel, A.; Khan, F.H.; Khan, N.I. Mulching as water-saving technique in dryland agriculture: Review article. Bull. Natl. Res. Cent. 2019, 43, 147. [CrossRef]

53. Hoorman, J.J. Using Cover Crops to Improve Soil and Water Quality. Ohio State University Sustainable Agriculture Fact Sheets. 2009. Available online: http:/ / ohioline.osu.edu/factsheet/anr-57 (accessed on 22 August 2021).

54. Dabney, S.M.; Delgado, A.; Reeves, D.W. Using winter cover crops to improve soiland water quality. Commun. Soil Sci. Plant Anal. 2001, 32, 1221. [CrossRef]

55. Popay, I.; Field, R. Grazing Animals as Weed Control Agents. Weed Technol. 1996, 10, 217-231. [CrossRef]

56. Santos Valle, S.; Kienzle, J. Agriculture 4.0-Agricultural Robotics and Automated Equipment for Sustainable Crop Production. In Integrated Crop Management; FAO: Rome, Italy, 2020; Volume 24, Available online: http:/ / www.fao.org/3/cb2186en/CB218 6EN.pdf (accessed on 24 August 2021).

57. Monteiro, A.; Santos, S.; Gonçalves, P. Precision Agriculture for Crop and Livestock Farming-Brief Review. Animals 2021, 11, 2345. [CrossRef]

58. Zhang, Q. Precision Agriculture Technology for Crop Farming; CRC Press: Boca Raton, FL, USA, 2015.

59. Dammer, K.H.; Wartenberg, G. Sensor-based weed detection and applicationof variable herbicide rates in real time. Crop. Prot. 2007, 26, 270-277. [CrossRef]

60. Lima, A.; Mendes, K. Variable Rate Application of Herbicides for Weed Management in Pre- and Postemergence. In Pests, Weeds and Diseases in Agricultural Crop and Animal Husbandry Production, Dimitrios Kontogiannatos; Kourti, A., Mendes, K.F., Eds.; IntechOpen: London, UK, 2020. [CrossRef]

61. Forouzanmehr, E.; Loghavi, M. Design, development and field evaluation of a map-based variable rate granular fertilizer application control system. Agric. Eng. Int. CIGR J. 2012, 14, 255-264.

62. Zhang, Y.; Staab, E.S.; Slaughter, D.C.; Giles, D.K.; Downey, D. Precision automated weed control using Hyperspectral vision identification and heated oil. ASABE Tech. Libr. 2009, 21-24. [CrossRef]

63. Søgaard, H.T.; Lund, I. Application accuracy of a machine vision-controlled robotic micro-dosing system. Biosyst. Eng. 2007, 96, 315-322. [CrossRef]

64. Kargar, B.; Shirzadifar, M. Automatic weed detection system and smart herbicide sprayer robot for corn fields. In Proceedings of the 2013 First RSI/ISM International Conference on Robotics and Mechatronics (ICRoM), Tehran, Iran, 13-15 February 2013; pp. $468-473$.

65. Burgos, N.R.; Rouse, C.E.; Singh, V.; Salas-Perez, R.; Bagavathiannan, M. Technological Advances for Weed Management. In APWSS 50th Anniversary Celebratory; Chandrasena, N., Rao, A.N., Eds.; Asian-Pacific Weed Science Society (APWSS) Publication: Honolulu, HI, USA, 2017; pp. 65-79.

66. Gómez-Candón, D.; Virlet, N.; Labbé, S.; Jolivot, A.; Regnard, J.L. Field phenotyping of water stress at tree scale by UAV-sensed imagery: New insights for thermal acquisition and calibration. Precis. Agric. 2016, 17, 786-800. [CrossRef]

67. Rani, A.; Chaudhary, A.; Sinha, N.; Mohanty, M.; Chaudhary, R. Drone: The green technology for future agriculture. Har. Dhara 2019, 2, 3-6.

68. Ahmad, A.; Ordoñez, J.; Cartujo, P.; Martos, V. Remotely Piloted Aircraft (RPA) in Agriculture: A Pursuit of Sustainability. Agronomy 2021, 11, 7. [CrossRef]

69. Jiménez-Brenes, F.M.; López-Granados, F.; Torres-Sánchez, J.; Peña, J.M.; Ramírez, P.; Castillejo-González, I.L. Automatic UAV-based detection of Cynodon dactylon for site-specific vineyard management. PLoS ONE 2019, 14, e0218132. [CrossRef]

70. Hassanein, M.; El-Sheimy, N. An efficient weed detection procedure using low-cost UAV imagery system for precision agriculture applications. Int. Arch. Photogramm. Remote. Sens. Spat. Inf. Sci. 2018, 42, 181-187. [CrossRef]

71. King, A. Technology: The Future of Agriculture. Nature 2017, 544, S21-S23. [CrossRef]

72. Peruzzi, A.; Martelloni, L.; Frasconi, C.; Fontanelli, M.; Pirchio, M.; Raffaelli, M. Machines for non-chemical intra-row weed control: A review. J. Agric. Eng. 2017, 48, 57-70. [CrossRef]

73. Fernandez-Quintanilla, C.; Peña-Barragán, J.M.; Andújar, D.; Dorado, J.; Ribeiro, A.; López-Granados, F. Is the current state-ofthe-art of weed monitoring suitable for site-specific weed management in arable crops? Weed Res. 2018, 58, 259-272. [CrossRef]

74. Riar, D.S.; Ball, D.A.; Yenish, J.P.; Burke, I.C. Light-activated, sensor-controlled sprayer provides effective postemergence control of broadleaf weeds in fallow. Weed Technol. 2011, 25, 447-453. [CrossRef]

75. Berge, T.; Goldberg, S.; Kaspersen, K.; Netland, J. Towards machine vision based site-specific weed management in cereals. Comput. Electron. Agric. 2012, 81, 79-86. [CrossRef]

76. Jensen, H.; Jacobsen, L.; Pedersen, S.; Tavella, E. Socioeconomic impact of widespread adoption of precision farming and controlled traffic systems in Denmark. Precis. Agric. 2012, 13, 661-677. [CrossRef] 